\title{
Evaluation of photodynamic therapy on fibroblast viability and cytokine production
}

\author{
João Eduardo Gomes-Filho ${ }^{\mathrm{a}}$, Gustavo Sivieri-Araujo ${ }^{\mathrm{a}, *}$, Carla Renata Sipert $^{\mathrm{b}}$, \\ Ludmilla Mota da Silva Santos ${ }^{a}$, Índia Olinta de Azevedo Queiroz ${ }^{a}$, \\ Christine Men Martins ${ }^{a}$, Nayara Kívilla do Carmo Maia ${ }^{a}$, Luciano Tavares Angelo Cintra ${ }^{a}$, \\ Eloi Dezan-Junior ${ }^{a}$, Vanderlei Salvador Bagnato ${ }^{c}$, Antônio Hernandes Chaves-Neto ${ }^{\mathrm{d}}$, \\ Sandra Helena Penha de Oliveira ${ }^{\mathrm{e}}$ \\ a Department of Restorative Dentistry, Discipline of Endodontics, Araçatuba School of Dentistry, São Paulo State University, Araçatuba, SP, Brazil \\ b Department of Restorative Dentistry, Discipline of Endodontics, Dental School, University of São Paulo, São Paulo, SP, Brazil \\ c Optics Group, Physics Institute of São Carlos, University of São Paulo, São Carlos, SP, Brazil \\ ${ }^{\mathrm{d}}$ Department of Basic Science, Discipline of Biochemistry, Araçatuba School of Dentistry, São Paulo State University, Araçatuba, SP, Brazil \\ e Department of Basic Science, Discipline of Pharmacology, Araçatuba School of Dentistry, São Paulo State University, Araçatuba, SP, Brazil
}

\section{A R T I C L E I N F O}

\section{Article history:}

Received 12 September 2015

Received in revised form

19 December 2015

Accepted 14 January 2016

Available online 18 January 2016

\section{Keywords:}

Endodontic treatment

Root canal irrigants

Photodynamic therapy

Cytotoxicity

Cytokine

\begin{abstract}
A B S T R A C T
Background: The aim of this study was to evaluate the effects of photodynamic therapy with curcumin (PDT) comparatively to $5 \%$ sodium hypochlorite $(\mathrm{NaOCl})$ and saline solution on cell viability and cytokine (IL-1 $\beta$ and IL-6) production by mouse fibroblasts.

Methods: Sixty seconds of pre-irradiation time with curcumin $500 \mathrm{mg} / \mathrm{L}$ and Led wavelength $(\lambda) 480 \mathrm{~nm}$, $72 \mathrm{~J} \mathrm{~cm}^{2}$, for $300 \mathrm{~s}$ was used for PDT. Solutions were diluted in culture medium DMEM $\left(1 \times 10^{4}\right.$ cells $)$ and placed into 24-well cell culture plates with mouse fibroblasts L-929. Culture medium was used as control. After 6, 24 and 48 h, 3-(4,5-dimethylthiazol-2-yl)-2,5-diphenyl tetrazolium bromide assay (MTT) was used to evaluate the cell viability and the supernatant was collected for cytokine evaluation using enzyme-linked immunosorbent assay (ELISA). The results were statistically analyzed by ANOVA and BonFerroni correction $(p<0.05)$ for MTT and Kruskal-Wallis test and Dunn $(p<0.05)$ for ELISA.

Results: PDT and saline solution presented low cytotoxic effect similar to the control group $(p>0.05)$ while $5 \% \mathrm{NaOCl}$ was more cytotoxic than PDT $(p<0.05)$ in all periods of time. All materials similarly expressed IL-1 $\beta$ and IL-6 regardless to the experimental period $(p<0.05)$.

Conclusions: PDT with curcumin was not cytotoxic to L929 fibroblasts differently from $5 \% \mathrm{NaOCl}$. In all groups occurred similar expression of IL-1 $\beta$ and IL-6.
\end{abstract}

(c) 2016 Elsevier B.V. All rights reserved.

\section{Introduction}

Root canal cleaning and shaping are essential to reduce and/or eliminate the population of micro-organisms (MO) and their toxic products (endotoxins and apical biofilm) present in endodontic

\footnotetext{
* Corresponding author. Fax: +55 1836363253.

E-mail addresses: joao@foa.unesp.br (J.E. Gomes-Filho), gustavosivieri@uol.com.br(G. Sivieri-Araujo), carlasipert@gmail.com (C.R. Sipert), ludmillasantos@yahoo.com.br (L.M. da Silva Santos),indiaodonto@gmail.com (Í.O. de Azevedo Queiroz), christinemen@hotmail.com (C. Men Martins), kivilla@hotmail.com (N.K. do Carmo Maia), lucianocintra@foa.unesp.br (L.T.A. Cintra), dezan@foa.unesp.br (E. Dezan-Junior),vander@ifsc.usp.br (V.S. Bagnato), antoniohernandes@foa.unesp.br (A.H. Chaves-Neto), shpoliv@foa.unesp.br (S.H.P. de Oliveira).
}

infection [1]. The use of irrigating solution that assist cleaning during endodontic treatment is essential to maximize the decontamination by its chemical action [2].

Sodium hypochlorite $(\mathrm{NaOCl})$ is the most employed irrigation solution primarily for its antimicrobial action [2,3]. However, despite the scientific-technical progress, authors show the persistence of MO in root canal system post-treatment $[1,2,4]$. Therefore, new therapeutic strategies must be investigated to potentiate the combat of endodontic infections.

Recently new methods as photodynamic therapy (PDT) are used on treatments to promote disinfection in periodontitis, dental caries, endodontic diseases, among other dental specialties [5-7]. Photodynamic therapy uses specific wavelength light Laser (light amplification by stimulated emission of radiation) or Led 
(light emitting diode) that activates the photosensitizer (PS) and produces highly reactive specie of oxygen (singlet oxygen) inactivating the target cell $[8,9]$ and assists antimicrobial action without the risk to promote microbial resistance [10]. Several kinds of PS may be associated with Laser or Led: hematoporphyrin derivatives, porphyrin, phenothiazine (toluidine blue and methylene blue), chlorophyll, fluorones (rhodamine B), cyanine phytotherapic agents, phthalocyanines and curcumin [5,11]. Curcumin, a compound from Curcuma longa L., the drug has a variety of applications, including treatment of liver diseases, wounds, inflamed joints and microbial effects $[6,12,13]$.

In vitro studies with porphyrin and methylene blue PS [14] and in vivo studies with chlorophyll and methylene blue PS [14-17] demonstrated PDT as a new antimicrobial therapeutic modality aiming to increase the disinfection of root canal system during endodontic treatment. It was also evidenced with toluidine blue PS in PDT against Enterococcus faecalis once PS fixes in the cell membrane and reaches the peak of absorption leading to generation of singlet oxygen, which destroys cellular wall and leads to bacterial death [18]. However, Frota et al. [19], did not show total disinfection of root canals PDT against E. faecalis with curcumin PS.

Although PDT has been already employed for tumor treatment in oncology [20] its cytotoxicity effect is not completely understood, especially when using curcumin as a photosensitizer. Thus, the aim of this study was to determine the effects of PDT with curcumin comparatively to $5 \% \mathrm{NaOCl}$ and saline solution on fibroblasts viability and on IL-1 $\beta$ and IL-6 cytokine releasing.

\section{Materials and methods}

\subsection{Fibroblasts culture}

L-929 mouse lineage fibroblasts were maintained in culture bottles with Dulbecco's modified Eagle's medium (DMEM) supplemented with $10 \%$ fetal bovine serum (GIBCO BRL, Gaithersburg, MD, USA), streptomycin $(50 \mathrm{~g} / \mathrm{mL})$, and $1 \%$ antibiotic/antimycotic cocktail (300 units/mL penicillin, $300 \mu \mathrm{g} / \mathrm{mL}$ streptomycin, $5 \mu \mathrm{g} / \mathrm{mL}$ amphotericin B and $200 \mu \mathrm{g} / \mathrm{mL}$ of glutamin) (GIBCO BRL, Gaithersburg, MD, USA). The cultures were maintained under standard cell culture conditions $\left(37^{\circ} \mathrm{C}, 100 \%\right.$ humidity, $\left.5 \% \mathrm{CO}_{2}\right)[21,22]$.

\subsection{Group division and photodynamic therapy}

It was used $50 \mu \mathrm{L}$ of each solution diluted in $450 \mu \mathrm{L}$ of DMEM. The solutions were 20 times more concentrated to get the desired concentration after dilution. A total volume of $500 \mu \mathrm{L}$ was inserted in each well. The groups were distributed as follow: G1-Culture medium (control); G2-5\% NaOCl; G3-Saline solution; G4-PDT.

The PDT was performed with curcumin at $500 \mathrm{mg} / \mathrm{L}[1,7-$ bis-(4-hydroxy-3-methoxyphenyl)-1,6-heptadiene-3,5-dione] (PDTPharma, Cravinhos, SP, Brazil), in the period of $60 \mathrm{~s}$ of preirradiation as recommended by Paschoal et al., 2013 [6]. Then the PS was activated with blue Led for $\lambda 480 \mathrm{~nm}, 72 \mathrm{~J} \mathrm{~cm}^{2}$, (Physics Institute of São Carlos, University of São Paulo, São Carlos, SP, Brazil) for $300 \mathrm{~s}$ [6]. During the pre-irradiation of PS and also during the activation of the LED, the lighting of the laminar flow chamber was turned off and the ambient light in the laboratory was reduced to avoid PS degradation.

\subsection{Cytotoxicity testing}

L929 fibroblasts were seeded into the 24 -well plates $\left(1 \times 10^{4}\right.$ cell/well). The cells were incubated for $24 \mathrm{~h}$ in a humidified air atmosphere of $5 \% \mathrm{CO}_{2}$ at $37^{\circ} \mathrm{C}$. The solutions were tested for $6 \mathrm{~h}$, $24 \mathrm{~h}$ and $48 \mathrm{~h}$. Tree wells were used for each solutions, and wells with DMEM were used as the control. Viable cells were stained with

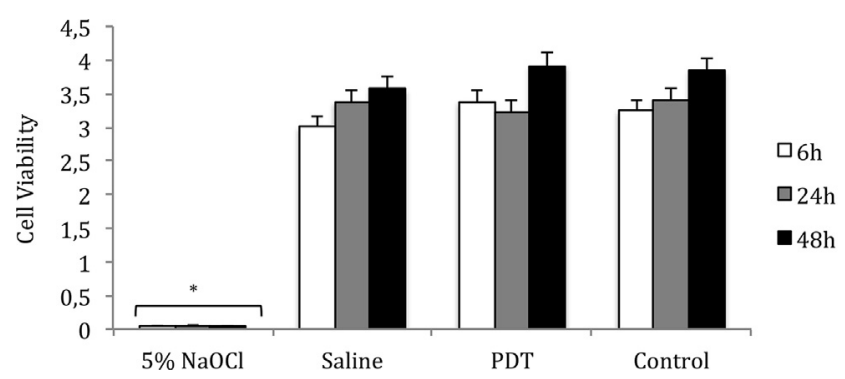

Fig. 1. Viability of fibroblasts in the presence of PDT and irrigating solutions, the periods $6 \mathrm{~h}, 24 \mathrm{~h}$ and $48 \mathrm{~h} .{ }^{*}(p<0.05)$ indicates significant statistical difference.

formazan dye (3-[4,5-dimethylthiazol-2-yl]-2,5-diphenyl tetrazolium bromide) (MTT) (Sigma Chemical Co., St. Louis, MO) that was dissolved in phosphate- buffered saline at $5 \mathrm{mg} / \mathrm{mL}$ and filtered in order to sterilize and remove a small amount of insoluble residue. At the experimental times, stock MTT solution $(40 \mu \mathrm{L}$ per $360 \mu \mathrm{L}$ medium) was added to all wells of an assay, and plates were incubated at $37^{\circ} \mathrm{C}$ for $3 \mathrm{~h}$. The medium was then removed by the inversion of the plate and $200 \mathrm{~mL}$ of isopropilic alcohol was added to the wells and mixed during 20 minutes in order to dissolve the dark blue crystals. The blue solution was transferred to a 96-well plate, and the absorbance was read in the microplate reader using $570 \mathrm{~nm}$ wavelength [23]. The treatments were classified according to the cytotoxic effect of: 0-non-cytotoxic (less inhibition than 25\%); 1 -slightly cytotoxic (inhibition between $25 \%$ and 50\%); 2-moderately cytotoxic (inhibition between $50 \%$ and 75\%) and 3-strongly cytotoxic (greater than 75\% inhibition). Assays were performed in triplicate.

\subsection{Enzyme-linked immunosorbent assay}

For cytokine assay, supernatant samples were used in the experiment originated from cytotoxicity to analyze the production of cytokines (IL-1 $\beta$ and IL-6) by fibroblasts, according to Gomes-Filho et al. [21,22]. After the incubation periods, supernatants were collected and analyzed to detect were measured using Peprotech Murine IL-1 $\beta$ and IL-6 mini ELISA development kits (Manufacturer, Rocky Hill, NJ, USA), according to the manufacturer's instructions. This assay also revealed the presence and levels of IL-1 $\beta$ and IL$6(\mathrm{pg} / \mathrm{ml})$. Wells with no added GT solution or irrigant, but with cell culture served as a control. The measurements were made in triplicate.

\subsection{Statistical analysis}

The results were statistically analyzed by ANOVA test with BonFerroni correction $(p<0.05)$ for MTT and Kruskal-Wallis test and Dunn's $(p<0.05)$ for ELISA.

\section{Results}

MTT assay in the periods of $6 \mathrm{~h}, 24 \mathrm{~h}$ and $48 \mathrm{~h}$ is shown in Fig. 1. It was revealed that control, saline solution, and PDT did inhibit less than $25 \%$ the cell viability. The same result was not seen in the $5 \%$ $\mathrm{NaOCl}$ group that was greater than $75 \%$ inhibition and was the most cytotoxic $(p<0.05)$.

The mean concentrations of IL-1 $\beta$ for the different groups are shown in Fig. 2a. All groups were able to induce similar IL-1 $\beta$ production observed by ELISA assay $(p<0.05)$.

The expression of IL- 6 are shown in Fig. $2 b$. ELISA assay revealed that the mean concentrations of IL- 6 was similar among the groups $(p>0.05)$, although $5 \% \mathrm{NaOCl}$ had been highly cytotoxic. 

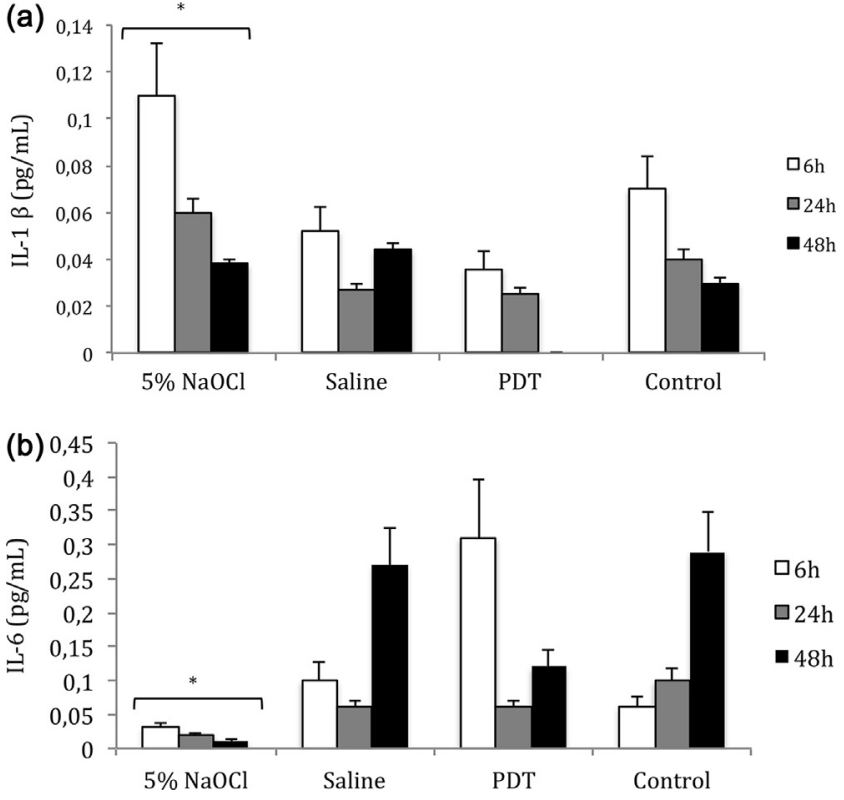

Fig. 2. Mean levels of IL-1 $\beta$ (a) and IL-6 (b) were raised when the cells were grown in the presence of the solutions, the periods $6 \mathrm{~h}, 24 \mathrm{~h}$ and $48 \mathrm{~h} .{ }^{*}(p<0.05)$ indicates significant statistical difference.

\section{Discussion}

The cell viability was determined in this study by 3-(4,5dimethylthiazol-2-yl)-2,5-diphenyl tetrazolium bromide assay (MTT) based on the ability of mitochondrial dehydrogenase enzymes in living cells to convert the yellow water-soluble tetrazolium salt MTT into dark blue formazan crystals, a simple method that showed advantages as rapidness and precision $[21,22]$ and the substrate used in the assay does not interfere with measurement end [23]. Complementary, ELISA assay was used for the measured the cytokines secreted.

In the present study, it was observed that $5 \% \mathrm{NaOCl}$ was highly cytoxic observed by the low cell viability similarly to previous study [24]. These results can be explain due the chemical properties of $\mathrm{NaOCl}$ as ability to dissolve organic tissue $[25,26]$ and its toxicity due to the recruitment of expressive number of inflammatory cells [27].

The concentration of curcumin PS associated with $72 \mathrm{~J} \mathrm{~cm}^{2}$ of blue Led was biocompatible agreement with a previous in vivo study [28]. The present study employed a blue Led $\lambda 480 \mathrm{~nm}$, because curcumin PS has an absorption peak ranging between 300 and $500 \mathrm{~nm}$, according with Paschoal et al. [6].

Saline solution and PDT were capable to maintain the cell viability similar to that observed for control during all periods evaluated. These results are similar to previous studies that have showed that PDT did not affect host cell viability from gingival fibroblasts, osteoblasts, and human periodontal ligament cells [22-31]. On the other hand, disagree with others that have showed that PDT promoting reduction in fibroblast, macrophage and human head $[32,33]$. The differences can be due to concentrations, treatment protocol, or cell types.

The synthesis of cytokines is very complex, and their expression and effects are governed by many factors that include other cells and mediators $[21,22]$. During inflammatory process, numerous pro- and anti-inflammatory cytokines are secreted such as IL-1 and IL-6 [21]. IL-1 is a cytokine that mediates the bone resorption after synthesis by macrophages; it is an important mediator of the inflammatory response, involved in a variety of cellular activities, including cell proliferation, differentiation, and apoptosis $[34,35]$.
On the other hand, IL-6 is a cytokine that mediates the host response to injury and infection, and it is secreted during the inflammatory process after tumor necrosis factor-alpha (TNF- $\alpha$ ) and IL- 1 secretion, consequently IL- 6 inhibits the secretion of TNF- $\alpha$ and IL-1 $[36,37]$. All irrigants investigated were able to express similarly Il6 and IL- $1 \beta$ cytokines, even $5 \% \mathrm{NaOCl}$ that was highly cytotoxic agreeing to previous studies that showed that $\mathrm{NaOCl}$ even being toxic can express cytokines [38]. It is important to consider that a small amount of cells remained after exposure to $5 \% \mathrm{NaOCL}$ inferring that proportionally the cytokine release after its contact had been expressively higher than the other solutions converging to its high cytotoxicity.

Previous studies showed that PDT has immunomodulatory activity and was capable to modulate host response reducing the capacity to stimulate the proliferation of $T$ cells $[39,40]$. In the present study, PDT stimulated the production of IL-1 $\beta$ and IL- 6 by fibroblasts agreeing to previous study that showed PDT inducing IL-1 $\beta$ and IL-6 secretion [41]. By the other hand, disagree to studies that showed that PDT decreased cytokines production [42] or promoted the inactivation of key proinflamatory markers [43]. The differences can be due to the photosensitizer, treatment protocol, or cell types. In the present study, it was used the previously described drug and light parameters [6]. After PDT, molecular biological mechanisms lead to biostimulation (increased proliferation rate), repair of the damage leading to rescue of the cells, autophagy, apoptosis and necrosis. The different modes of cellular responses depend mainly on the PDT-protocol, photosensitizer localization, cellular damage protection and available intracellular energy [44]. This fact may also contribute to tissue repair and suggests the use of PDT in Endodontics.

\section{Conclusion}

According to the methodology employed, photodynamic therapy with curcumin was not cytotoxic and did not inhibit the L-929 fibroblasts viability and release of cytokines IL-1 $\beta$ and IL-6.

\section{Conflict of interest}

The authors declare that they have no conflict of interest.

\section{Acknowledgements}

This work was supported by Fundação de Amparo à Pesquisa do Estado de São Paulo-FAPESP (Grant numbers: 2011/23287-8, 2012/12695-0 and 2012/06785-7).

\section{References}

[1] J. Vera, J.F. Siqueira Jr., D. Ricucci, et al., One-versus two-visit endodontic treatment of teeth with apical periodontitis: a histobacteriologic study, J. Endod. (2012), http://dx.doi.org/10.1016/j.joen.2012.04.010.

[2] M. Haapasalo, Y. Shen, Z. Wang, et al., Irrigation in endodontics, Br. Dent. J. (2014), http://dx.doi.org/10.1038/sj.bdj.2014.204.

[3] A. Del Carpio-Perochena, C.M. Bramante, F.B. de Andrade, et al., Antibacterial and dissolution ability of sodium hypochlorite in different $\mathrm{pHs}$ on multi-species biofilms, Clin. Oral Investig. 26 (February) (2015) [Epub ahead of print].

[4] P.N. Nair, S. Henry, V. Cano, et al., Microbial status of apical root canal system of human mandibular first molars with primary apical periodontitis after one-visit endodontic treatment, Oral Surg. Oral Med. Oral Pathol. Oral Radiol. Endod. (2005), http://dx.doi.org/10.1016/j.tripleo.2004.10.005.

[5] J.S. Giusti, C.R. Fontana, O.C. Guimarães, et al., Single equipment combines simultaneous application of mechanical ultrasound and photodynamic action for microbial control, Photodiagn. Photodyn. Ther. (2010), http://dx.doi.org/ 10.1016/j.pdpdt.2010.03.004.

[6] M.A. Paschoal, C.C. Tonon, D.M. Spolidório, et al., Photodynamic potential of curcumin and blue LED against Streptococcus mutans in a planktonic culture, Photodiagn. Photodyn. Ther. (2013), http://dx.doi.org/10.1016/j.pdpdt.2013. 02.002 . 
[7] A.S. Garcez, J.G. Neto, D.P. Sellera, et al., Effects of antimicrobial photodynamic therapy and surgical endodontic treatment on the bacterial load reduction and periapical lesion healing. Three years follow up, Photodiagn. Photodyn. Ther. (2015), http://dx.doi.org/10.1016/j.pdpdt.2015.06.002.

[8] A. Shrestha, M. Cordova, A. Kishen, Photoactivated polycationic bioactive chitosan nanoparticles inactivate bacterial endotoxins, J. Endod. (2015), http://dx.doi.org/10.1016/j.joen.2014.12.007.

[9] R.R. Allison, H.C. Mota, V.S. Bagnato, et al., Bio-nanotechnology and photodynamic therapy-state of the art review, Photodiagn. Photodyn. Ther. (2008), http://dx.doi.org/10.1016/j.pdpdt.2008.02.001.

[10] L. López-Jiménez, E. Fusté, B. Martínez-Garriga, et al., Effects of photodynamic therapy on Enterococcus faecalis biofilms, Lasers Med. Sci. (2015), http://dx. doi.org/10.1007/s10103-015-1749-y.

[11] P. Neelakantan, C.Q. Cheng, V. Ravichandran, et al., Photoactivation of curcumin and sodium hypochlorite to enhance antibiofilm efficacy in root canal dentin, Photodiagn. Photodyn. Ther. (2015), http://dx.doi.org/10.1016/j. pdpdt.2014.10.011.

[12] D. Manoil, A. Filieri, C. Gameiro, et al., Flow cytometric assessment of streptococcus mutans viability after exposure to blue light-activated curcumin, Photodiagn. Photodyn. Ther. (2014), http://dx.doi.org/10.1016/j. pdpdt.2014.06.003.

[13] G. Pileggi, J.C. Wataha, M. Girard, et al., Blue light-mediated inactivation of Enterococcus faecalis in vitro, Photodiagn. Photodyn. Ther. (2013), http://dx. doi.org/10.1016/j.pdpdt.2012.11.002.

[14] C.P. Sabino, A.S. Garcez, S.C. Nunez, et al., Real-time evaluation of two light delivery systems for photodynamic disinfection of Candida albicans biofilm in curved root canals, Lasers Med. Sci. (2014), http://dx.doi.org/10.1007/s10103014-1629-X.

[15] A.S. Garcez, S.C. Nuñez, M.R. Hamblin, et al., Antimicrobial effects of photodynamic therapy on patients with necrotic pulps and periapical lesion, J. Endod. (2008), http://dx.doi.org/10.1016/j.joen.2007.10.020.

[16] L.A. Silva, A.B. Novaes Jr., R.R. Oliveira, et al., Antimicrobial photodynamic therapy for the treatment of teeth with apical periodontitis: a histopathological evaluation, J. Endod. (2012), http://dx.doi.org/10.1016/j. joen.2011.12.023.

[17] N.S. Soukos, P.S. Chen, J.T. Morris, et al., Photodynamic therapy for endodontic disinfection, J. Endod. (2006), http://dx.doi.org/10.1016/j.joen.2006.04.007.

[18] C. Tennert, A.M. Drews, V. Walther, et al., Ultrasonic activation and chemica modification of photosensitizers enhances the effects of photodynamic therapy against Enterococcus faecalis root-canal isolates, Photodiagn. Photodyn. Ther. (2015), http://dx.doi.org/10.1016/j.pdpdt.2015.02.002.

[19] M.F. Frota, J.M. Guerreiro-Tanomaru, M. Tanomaru-Filho, et al., Photodynamic therapy in root canals contaminated with Enterococcus faecalis using curcumin as photosensitizer, Lasers Med. Sci. (2014), http://dx.doi.org/10. 1007/s10103-014-1696-z.

[20] S.P. Singh, M. Sharma, P.K. Gupta, et al., Enhancement of phototoxicity of curcumin in human oral cancer cells using silica nanoparticles as delivery vehicle, Lasers Med. Sci. (2014), http://dx.doi.org/10.1007/s10103-013-13577.

[21] J.E. Gomes-Filho, S. Watanabe, A.C. Gomes, et al., Evaluation of the effects of endodontic materials on fibroblast viability and cytokine production, J. Endod. (2009), http://dx.doi.org/10.1016/j.joen.2009.07.022.

[22] J.E. Gomes-Filho, A.C. Gomes, S. Watanabe, et al., Evaluation of tissue reaction, cell viability and cytokine production induced by sealapex plus, J. Appl. Oral Sci. (2011), http://dx.doi.org/10.1590/S1678-77572011005000006.

[23] T. Mosmann, Rapid colorimetric assay for cellular growth and survival: application to proliferation and cytotoxicity assays, J. Immunol. Methods (1983), http://dx.doi.org/10.1016/0022-1759(83)90303-4.

[24] G. Simbula, C. Dettori, T. Camboni, et al., Comparison of tetraacetylethylendiamine + sodium perborate and sodium hypochlorite cytotoxicity on L929 fibroblasts, J. Endod. (2010), http://dx.doi.org/10.1016/j. joen.2010.05.010.

[25] R. Holland, I.J. Soares, Soares Influence of irrigation and intracanal dressing on the healing process of dogs' teeth with apical periodontitis, Endod. Dent. Traumatol. 8 (1992) 223-229.
[26] T. Tartari, B.M. Guimarães, L.S. Amoras, et al., Etidronate causes minimal changes in the ability of sodium hypochlorite to dissolve organic matter, Int. Endod. J. (2015), http://dx.doi.org/10.1111/iej.12329.

[27] J.E. Gomes-Filho, K.G. Aurélio, M.M. Costa, et al., Comparison of the biocompatibility of different root canal irrigants, J. Appl. Oral Sci. (2008), http://dx.doi.org/10.1590/S1678-77572008000200011.

[28] N.C. Araújo, C.R. Fontana, M.E.M. Gerbi, et al., Overall-mouth disinfection by photodynamic therapy using curcumin, Photomed. Laser Surg. (2012), http:// dx.doi.org/10.1089/pho.2011.3053.

[29] Y. Xu, M.J. Young, R.A. Battaglino, et al., Endodontic antimicrobial photodynamic therapy: safety assessment in mammalian cell cultures, J. Endod. (2009), http://dx.doi.org/10.1016/j.joen.2009.08.002.

[30] H. Koon, A.W. Leung, K.K. Yue, et al., Photodynamic effect of curcumin on NPC/CNE2 cells, J. Environ. Pathol. Toxicol. Oncol. (2006) http://dx.doi.org/10. 1615.

[31] J. Qiao, S. Wang, Y. Wen, et al., Photodynamic effects on human periodontal-related cells in vitro, Photodiagn. Photodyn. Ther. (2014), http:// dx.doi.org/10.1016/j.pdpdt.2014.04.001.

[32] A.P. Ribeiro, A.C. Pavarina, L.N. Dovigo, et al., Phototoxic effect of curcumin on methicillin-resistant Staphylococcus aureus and L929 fibroblasts, Lasers Med. Sci. (2013), http://dx.doi.org/10.1007/s10103-012-1064-9.

[33] L.N. Dovigo, A.C. Pavarina, A.P. Ribeiro, et al., Investigation of the photodynamic effects of curcumin against Candida albicans, Photochem. Photobiol. (2011), http://dx.doi.org/10.1111/j. 1751-1097.2011.00937.x.

[34] J.C. Ahn, J.W. Kang, J.I. Shin, et al., Combination treatment with photodynamic therapy and curcumin induces mitochondria-dependent apoptosis in AMC-HN3 cells, Int. J. Oncol. (2012), http://dx.doi.org/10.3892/ijo.2012.1661.

[35] A. Salminen, U.K. Gursoy, S. Paju, et al., Salivary biomarkers of bacterial burden, inflammatory response, and tissue destruction in periodontitis, J. Clin. Periodontol. (2014), http://dx.doi.org/10.1111/jcpe.12234.

[36] G.T. Huang, M. Do, M. Wingard, et al., Effect of interleukin-6 deficiency on the formation of periapical lesions after pulp exposure in mice, Oral Surg. Oral Med. Oral Pathol. Oral Radiol. Endod. (2001), http://dx.doi.org/10.1067/moe. 2001.115025.

[37] R. Schindler, J. Mancilla, S. Endres, et al., Correlations and interactions in the production of interleukin-6 (IL-6), IL-1, and tumor necrosis factor (TNF) in human blood mononuclear cells: IL-6 suppresses IL-1 and TNF, Blood 75 (1990) 40-47

[38] M. Mohri, P.S. Reinach, A. Kanayama, et al., Suppression of the TNFalpha-induced increase in IL-1alpha expression by hypochlorite in human corneal epithelial cells, Invest. Ophthalmol. Vis. Sci. 43 (2002) 3190-3195

[39] D.E. King, H. Jiang, G.O. Simkin, et al., Photodynamic alteration of the surface receptor expression pattern of murine splenic dendritic cells, Scand. J. Immunol. (1999), http://dx.doi.org/10.1046/j. 1365-3083.1999.00498. x.

[40] D.W. Hunt, J.G. Levy, Immunomodulatory aspects of photodynamic therapy, Expert Opin. Investig. Drugs 7 (9) (1998) 57-64.

[41] T. Kushibiki, T. Tajiri, Y. Tomioka, et al., Photodynamic therapy induces interleukin secretion from dendritic cells, Int. J. Clin. Exp. Med. 3 (2010) $110-114$.

[42] V.H. Luchesi, S.P. Pimentel, M.F. Kolbe, et al., Photodynamic therapy in the treatment of class II furcation: a randomized controlled clinical trial, J. Clin. Periodontol. (2013), http://dx.doi.org/10.1111/jcpe.12121.

[43] P. Braham, C. Herron, C. Street, et al., Antimicrobial photodynamic therapy may promote periodontal healing through multiple mechanisms, J. Periodontol. (2009), http://dx.doi.org/10.1902/jop.2009.090214.

[44] B. Krammer, T. Verwanger, Molecular response to hypericin-induced photodamage, Curr. Med. Chem. (2012), http://dx.doi.org/10.2174/ 092986712799034842. 